\title{
The relevance of migration for the 2030 Agenda for Sustainable Development: The Global Compact for Safe, Orderly and Regular Migration, Constança Urbano de Sousa (ed.). Lisboa: Universidade Autónoma de Lisboa, 2019, ISBN 978-989-8191-95-3
}

\section{LUÍs MOITA*}

Imoita@autonoma.pt

GALILEU - REVISTA DE DIREITO E ECONOMIA · e-ISSN 2184-1845

Volume XX $\cdot 1^{\text {st }}$ January Janeiro $-30^{\text {TH }}$ June Junho $2019 \cdot$ pp. 164-166

DOI: ???

Em 1 de Outubro de 2018, por iniciativa conjunta do centro de investigação em Direito, Ratio Legis, e do centro de investigação em Relações Internacionais, OBSERVARE, da Universidade Autónoma de Lisboa, realizou-se um Seminário de âmbito internacional sobre o tema das migrações, com o apoio do Instituto Camões e da Fundação para a Ciência e a Tecnologia. A alma deste importante encontro científico foi a Professora Constança Urbano de Sousa, uma autoridade em assuntos jurídicos e com notável experiência internacional neste domínio, ligada a ambos os centros em causa. Ela própria promoveu a edição de um livro que concentra os conteúdos da Conferência, um belo volume intitulado The Relevance of Migration FOR THE 2030 AGENDA FOR SUSTAINABLE DeVelopment, com o subtítulo The Global Compact for Safe, Orderly and Regular Migration. Tal enunciado exprime ele próprio um programa. Um programa de flagrante actualidade. Um importante documento, conhecido como Pacto Global, fora aprovado pelas Nações Unidas no mês de Julho e, poucas semanas depois desta conferência em Lisboa, seria formalmente adoptado por 164 países na Cimeira de Marraquexe.

Por feliz coincidência, o Seminário contou com três intervenções, transcritas na edição em livro, de proeminentes portugueses colocados em lugares de elevada responsabilidade: o Presidente da República, Marcelo Rebelo de Sousa, o Ministro dos Negócios Estrangeiros, Augusto Santos Silva, e o Director Geral da OIM, António Vitorino. Tal referência, longe de pretender aludir a uma espécie de carácter oficioso se não mesmo oficial da iniciativa, visa tão-somente apontar para o facto de esses altos responsáveis estarem solidários com uma visão humanizante e politicamente irrepreensivel da questão migratória. O primeiro, Marcelo Rebelo de Sousa, salienta o desafio cultural, político, económico e 
social, mas sobretudo ético, que o problema envolve. O segundo, Augusto Santos Silva, destaca a responsabilidade do mundo académico e a necessária solidez das abordagens científicas. O terceiro, António Vitorino, abre com um prefácio onde expõe os grandes temas do Compacto Global. Essas intervenções de pendor político estão em consonância com os estudos científicos e as análises sociais que a obra integra, seja em perspectiva jurídica, seja na vertente sociológica.

Estamos perante um processo onde se joga uma dimensão decisiva da governação global. Num tempo, justamente, em que as migrações se globalizaram, elas constituem um fenómeno de enorme envergadura, mas carenciado de regulação assumida pela comunidade internacional. Ora a Cimeira de Marraquexe constituiu um momento privilegiado que assinala mais um marco no caminho para a gestão da globalidade. Assim como a ECO 92, a Cimeira da Terra, no Rio de Janeiro, em 1992, representou uma etapa fundamental na consciência colectiva, no caso em torno da questão ecológica, talvez o pacto de Marraquexe em 2018, apesar de não ser juridicamente vinculativo, adquira idêntico significado para as práticas colectivas no domínio das migrações, considerando-as nas suas multiformes dimensões (individuais e colectivas, laborais e económicas, sociais e legais, geopolíticas e de segurança). Por alguma razão as migrações são desejavelmente qualificadas como seguras, ordeiras e regu- lares. Estes temas são desenvolvidos no livro em apreço numa perspectiva ampla, fruto de enriquecedores contributos vindos de diversas latitudes, como boa prática do dialogo inter-universitário.

Ao tratar estes assuntos, parece evidente que o Seminário internacional superou a habitual visão securitária do fenómeno migratório - as migrações percepcionadas essencialmente como ameaça - em nome de uma visão que parte da centralidade dos direitos humanos, de acordo com a tradição milenar que nos vincula ao acolhimento de estrangeiros e refugiados. Pode parecer um detalhe de menor importância, mas a verdade é que essa mudança de focagem significa uma alteração substancial na compreensão dos factos e na orientação das políticas.

Inevitavelmente o debate teria de considerar a problemática migratória no quadro europeu, não constituísse esse processo um penoso factor de crise no nosso Continente: Estados divididos, com políticas contraditórias, populações confusas, aproveitamentos demagógicos das difíceis situações vividas. Pior ainda, acordos imorais com países terceiros, transferindo para eles o odioso da contenção dos fluxos humanos. Não foi só com a Turquia onde, a troco de euros, se retiveram multidões de refugiados. É também com as mais que suspeitas milícias líbias que europeus negoceiam o impedimento do acesso através do deserto africano, de tal maneira que a fronteira sul da Europa já não é tanto 
delimitada pelo Mediterrâneo, linha de terríveis tragédias, como agora pelo Sara, nova fronteira securitária onde sucumbem novas vítimas.

Pelo menos quatro dos capítulos do livro estão centrados na óptica das políticas europeias. Num espaço de livre circulação de pessoas, mercadorias e capitais, criam-se barreiras insuportáveis aos fluxos humanos de migrantes e refugiados. Com a agravante de que o principal problema reside nos sistemas de representação colectiva. Quer dizer: em boa parte, a suposta "invasão" de estrangeiros que ameaça as nossas sociedades é literalmente uma construção mental, um processo cognitivo explorado pelas propagandas nacionalistas. Sendo assim um produto cultural, deve ser sujeito a crítica e reinterpretado de maneira adequada, o que será função dos meios intelectuais e responsabilidade das Universidades.

* Professor universitário - Universidade Autónoma de Lisboa (UAL). Investigador no OBSERVARE - Observatório de Relações Exteriores (Universidade Autónoma de Lisboa) 